\title{
Настойка прополиса для лечения и профилактики бактериальных респираторных инфекций бройлеров
}

\author{
Лыско С.Б., кандидат ветеринарных наук, ведущий научный сотрудник отдела ветеринарии сельскохозяйственной птицы, \\ зам. директора по научной работе \\ Задорожная М.В., кандидат ветеринарных наук, ведущий научный сотрудник, и.о. зав. отделом ветеринарии \\ сельскохозяйственной птицы \\ Сибирский НИИ птицеводства (СибНИИП) - филиал ФГБНУ «Омский аграрный научный центр»
}

\begin{abstract}
Аннотация: Для лечения и профилактики респираторных инфекций 6 птицебодстве широко применяют антибиотики, однако наличие резистентной микрофлоры снижает их активность и эфррективность проводимых мероприятий. Целью исследований было разработать эфрективные, научно и экономически обоснованные схемы лечения и профилактики ассоциатибных респираторных болезней иыплят-бройлероб бактериальной этиологии с применением препарата природного происхождения - настойки прополиса. Исследования проведень на инкубационных яйцах и бройлерах кросса «Росс-308». В результате разработаны и запатентованы способы применения настойки прополиса 6 период инкубации и при бырамивании бройлеров, которые снижают количество патогенных и условно-патогенных микроорганизмов в дыхательных путях бройлеров, в боздухе птицебодческих помещений и инкубаторах; повышают быводимость яии на 4,8\% и бывод иыплят на 4,2\%; босстанавливают физиологические процессы, активизируют естественную резистентность и обмен веществ; ускоряют сроки выздоровления при лечении; позволяют получать безопасную продукцию птицеводства без профилактического применения антибиотиков; повышают продуктивность и экономические показатели при производстве мяса бройлеров.
\end{abstract}

Ключебые слова: респираторная инфекция, настойка прополиса, иыплята-бройлеры, профилактика, лечение, инкубатор, бактериальная микрослора.

Введение. Бактериальные болезни занимают существенное место в патологии птиц и характеризуются полиэтиологичностью, значительной вариабельностью антигенного состава возбудителей $[1,2]$. Особое внимание заслуживают инфекционные болезни, связанные с поражением респираторного тракта, при которых посредством воздушно-капельной передачи происходит быстрое распространение возбудителей на значительное поголовье птицы [3]. Возросла роль условнопатогенной микрофлоры, которая в сочетании с эндогенными и экзогенными факторами повышает свою патогенность и ведет к заболеваниям в масштабе эпизоотий. Ассоциативное течение инфекций затрудняет диагностику и проведение лечебно-профилактических мероприятий $[4,5]$. Выбор препаратов и схем их применения имеет первостепенное значение при разработке эфффективных мер борьбы с бактериальными болезнями и их профилактики. Чаще всего с этой целью используют антибиотики. Однако широкое распространение антибиотикорезистентных штаммов микроорганизмов постоянно снижает их эфффективность. Проблема устойчивости бактерий к антибактериальным препаратам актуальна во всем мире, как в ветеринарии, так и в медицине [6-9]. Поиск и разработка новых антибактериальных средств, способов их применения является приоритетным направ- лением современной науки и практики.

Цель исследования - разработать и испытать эффективные, научно и экономически обоснованные схемы лечения и профилактики ассоциативных респираторных болезней цыплят-бройлеров бактериальной этиологии с применением препарата природного происхождения - настойки прополиса.

материал и методика исследований. Исследования проводили в отделе ветеринарии СибНИИП и на базе птицеводческого хозяйства. Объектами исследования были инкубационные яйца, эмбрионы, цыплятабройлеры кросса «Росс-308». В опытах использовали настойку 
прополиса (100 г прополиса, 80\% спирт до получения 1 л настойки) производства ООО «Гиппократ» (г. Самара).

Для профилактики респираторной инфекции в инкубаторе из инкубационных яиц были скомплектованы контрольная и опытная группы по 1000 шт. в каждой, которые были размещены в отдельных инкубаторах. В контрольной группе перед закладкой, с момента переноса и до вывода, проведена обработка парами формальдегида [10]. В опытной группе обработки осуществляли аэрозольно настойкой прополиса, разведенной водой 1:10, из расчета 0,25 л/м³ объема инкубатора перед закладкой и на 1 1,5, 18,5, 21,5 сутки инкубации, при экспозиции 60 мин.

С целью испытания схемы применения настойки прополиса для профилактики респираторной инфекции при выращивании цыплят-бройлеров из выведенного в инкубаторе молодняка по принципу аналогов были скомплектованы контрольная и опытная группы по 400 голов в каждой, которые размещены в 2 изолированных залах. Цыплята контрольной группы, согласно схеме, применяемой в хозяйстве, получали антибиотик тилмипул (0,3 мл/л воды) в возрастные периоды 1-3, 14-16, 25-27 дней, дополнительно проводили аэрозольную обработку воздуха птичника Экоцидом-С $(0,5 \%, 1$ л/100 м³, экспозиция 60 мин) на 1, 7, 14, 21-22, 28-29, 3536 дни выращивания. Цыплятам опытной группы выпаивали настойку прополиса (1 мл/л воды) в возрасте 1-5, 14-18, 25-30 дней в сочетании с аэрозольной обработкой воздуха настойкой прополиса (разведение 1:20, 0,5 л/100 м², экспозиция 60 мин) на 1, 7, 14, 21-22, 28-29, 35-36 дни выращивания. Продолжительность опыта - 42 дня.
Для апробации схемы лечения из 22-дневных цыплят-бройлеров с клиническими признаками респираторной инфекции, подтвержденной бактериологическим исследованием, по принципу аналогов были скомплектованы контрольная и опытная группы по 500 голов в каждой и размещены в изолированных залах. Для лечения в контрольной группе применяли антибиотик тилмипул $(0,3$ мл/л воды) в течение 5 дней, для аэрозольной обработки воздуха использовали 0,5\% Экоцид-С (1 л/100м³) 3 дня подряд. Птице опытной группы совместно с антибиотиком выпаивали настойку прополиса в дозе 1 мл/л воды в течение 5 дней, аэрозольную обработку проводили настойкой прополиса (разведение 1:20, 1 л/100м 3 , экспозиция 60 мин) один раз в день в течение 3 дней подряд. Наблюдение за опытной птицей осуществляли в течение 10 дней от начала лечения.

Профилактическую и терапевтическую эффрективность разработанных схем оценивали по проявлению клинических признаков у цыплят, их сохранности и живой массе, результатам инкубации. Определяли гематологические, биохимические и иммунологические показатели крови. Проводили бактериологические исследования воздуха, смывов со скорлупы инкубационных яиц, соскобов со слизистой оболочки гортани бройлеров. Рассчитывали также экономические показатели.

Отбор проб, выделение культур микроорганизмов и их идентификацию проводили в соответствии с существующими методиками с использованием простых (МПБ, МПА) и дифференциально-диагностических (Эндо, висмут-сульфит-агар, стафилококкагар, энтерококкагар, XLD-агар, Чапека, среда с тилуритом калия, Олькеницкого, Симмонса) пита- тельных сред. Морфологию изучали в мазках из суточных агаровых культур, окрашенных по Граму и Романовскому-Гимзе, биохимические свойства - посевом на среды Гисса с сахарами [11]. Микробиологическое исследование воздуха проводили седиментационным методом по Коху, расчет по формуле Омелянского [12]. Количество форменных элементов крови подсчитывали в счетной камере Горяева под микроскопом после предварительного разведения крови в эритроцитарных меланжерах красителем Болотникова. Общий белок определяли биуретовым, альбумин - бромкрезоловым методом с наборами реактивов Hospitex Diagnostics (Италия), содержание гемоглобина в крови - гемихромным методом с набором «ГЕМОСО-НОВО» (Россия). Бактерицидную активность сыворотки крови (БАСК) определяли по методу Теффера в модификации О.В. Смирновой и Т.А. Кузьминой [13]. Учет результатов осуществляли с помощью спектрофотометра Еlх800. Результаты исследований обрабатывали статистически с использованием критерия Стьюдента [14].

Результаты исследований и их обсуждение. Обработка инкубационных яиц настойкой прополиса препятствовала размножению микрофлоры на протяжении инкубации, и к 18,5 суткам снизила частоту выделения стафилококков с поверхности скорлупы инкубационных яиц на 40\%, бактерий группы кишечной палочки (БГКП) - на 60\%; общее микробное число в воздухе инкубаторов к 21,5 суткам инкубации - на 341 $\mathrm{KOE} / \mathrm{M}^{3}$, БГКП - на 48, стафилококков - на 129, энтерококков - на 79, микроскопических грибов - на 51 $\mathrm{KOE} / \mathrm{M}^{3}$ (табл. 1).

Снижение микробного фона в опытной группе положительно отразилось на результатах инкуба- 


\begin{tabular}{|c|c|c|}
\hline \multirow[t]{2}{*}{ Показатель } & \multicolumn{2}{|c|}{ Группа } \\
\hline & Контрольная & Опытная \\
\hline \multicolumn{3}{|c|}{ Микробная обсемененность скорлупы яиц на 18,5 сутки инкубации, \% (n=10): } \\
\hline стафилококки & 70,0 & 30,0 \\
\hline бактерии группы кишечной палочки & 60,0 & 0,0 \\
\hline \multicolumn{3}{|c|}{ 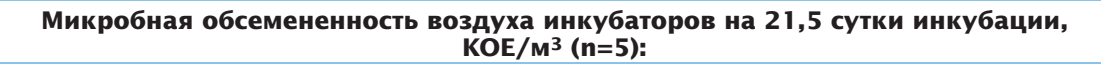 } \\
\hline общее микробное число & 713,2 & $372,3 * * *$ \\
\hline бактерии группы кишечной палочки & 140,1 & $92,4 *$ \\
\hline стафилококки & 197,3 & $68,1 *$ \\
\hline энтерококки & 98,1 & $19,2 * *$ \\
\hline микроскопические грибы & 168,2 & $117,2 *$ \\
\hline \multicolumn{3}{|c|}{ Результаты инкубации, \%: } \\
\hline гибель эмбрионов до 48 ч инкубации & 5,2 & 4,3 \\
\hline кровяное кольцо & 5,6 & 3,0 \\
\hline замершие & 2,6 & 1,7 \\
\hline задохлики & 3,5 & 2,2 \\
\hline Выводимость яиц & 81,9 & 86,7 \\
\hline вывод цыплят & 77,5 & 81,7 \\
\hline
\end{tabular}

Различия с контролем достоверны при: *P $<0,05 ;$ **P $<0,01 ; * * * \mathrm{P}<0,001$. ции и позволило повысить выводимость яиц на 4,8\%, по сравнению с контрольной группой, вывод цыплят - на 4,2\% за счет уменьшения количества категории «гибель эмбрионов до 48 часов» на 0,9\%, «кровяное кольцо» - на 2,6\%, «замерших» - на 0,9\%, «задохликов»-на 1,3\%.

При бактериологическом исследовании соскобов со слизистой оболочки гортани выведенных цыплят контрольной группы выделены Escherichia coli, Staphylococcus aureus, Enterococcus faecalis, Enterobacter agglomerans, Citrobacter freundii. У цыплят опытной группы изолированы только Enterococcus faecalis u Staphylococcus aureus. Микроорганизмы выделялись как в монокультуре, так и в ассоциациях, количество которых в контрольной группе составило 80\%, в опытной - 40\%. Таким образом, применение настойки прополиса в период инкубации санирует слизистые оболочки дыхательных путей цыплят и способствует профилактике респираторныхинфекций.

Аэрозольное применение настойки прополиса для профилактики респираторных инфекций при выращивании бройлеров в опытной группе достоверно сни- жало количество патогенных и условно-патогенных микроорганизмов в воздушной среде птичника и на слизистых оболочках верхних дыхательных путей бройлеров на протяжении всего опыта. Разница по содержанию микроорганизмов в воздухе опытной группы с контрольной к 42 дню выращивания бройлеров составила: по общему микробному числу - 1126 КОЕ/м³, БГКП - 283, стафилококкам - 299, энтерококкам 208, микроскопическим грибам $380 \mathrm{KOE} / \mathrm{M}^{3}$ (табл. 2).

\section{Таблица 2. Эффективность схем профилактики респираторных} инфекций при выращивании цыплят-бройлеров

Показатель

Контрольная Опытная

Микробная обсемененность воздуха в залах в возрасте птицы 42 дня, КОЕ/м³:

\begin{tabular}{|c|c|c|}
\hline общее микробное число & 2016,1 & $890,3 * * *$ \\
\hline бактерии группы кишечной палочки & 405,2 & $122,1 * * *$ \\
\hline стафилококки & 1123,3 & $824,1 * *$ \\
\hline энтерококки & 489,2 & $281,3 *$ \\
\hline микроскопические грибы & 714,1 & $334,0 * *$ \\
\hline \multicolumn{3}{|c|}{ Содержание в крови 42-дневных бройлеров: } \\
\hline эритроциты, 1012/л & 2,1 & $2,7^{*}$ \\
\hline лейкоциты, 109/л & 11,7 & $18,0 *$ \\
\hline гемоглобин, г/л & 60,5 & $74,5^{* *}$ \\
\hline общий белок, г/л & 32,9 & $36,6^{*}$ \\
\hline альбумин, г/л & 11,1 & 10,3 \\
\hline глобулины, г/л & 21,8 & $26,3 *$ \\
\hline БАСК, \% & 31,1 & 51,7 \\
\hline \multicolumn{3}{|c|}{ Экономические показатели: } \\
\hline сохранность, \% & 97,5 & 99,5 \\
\hline средняя живая масса в 42 дня жизни, кг & 1676,1 & $1912,7^{* * *}$ \\
\hline среднесуточное потребление корма, г/гол. & 91,3 & 84,0 \\
\hline затраты корма на 1 кг продукции, кг & 2,3 & 1,7 \\
\hline прибыль, руб. & 2131,5 & 11569,2 \\
\hline рентабельность, \% & 4,9 & 23,3 \\
\hline
\end{tabular}


чали на протяжении всего периода выращивания бройлеров. В 42дневном возрасте она на 236,6 г превышала контроль при снижении среднесуточного потребления корма на 7,3 г/гол., затрат корма на 1 кг продукции - на 0,6 кг. Сохранность цыплят опытной группы за период выращивания превышала показатель контроля на $2 \%$. Применение настойки прополиса по разработанной схеме способствовало профилактике респираторных инфекций при выращивании цыплят и позволило увеличить прибыль на 9437,76 руб., рентабельность выращивания бройлеров - на 18,3\%.

Аэрозольная обработка настойкой прополиса при лечении цыплят-бройлеров с респираторной инфекцией снижала в воздухе залов опытной группы общее микробное число на $139 \mathrm{KOE} / \mathrm{M}^{3}$, количество БГКП - на 10, стафилококков - на 170, энтерококков - на 13, микроскопических грибов - на $14 \mathrm{KOE} / \mathrm{M}^{3}$ по сравнению с контролем, где применяли Экоцид-С (табл. 3). В соскобах со слизистых оболочек гортани цыплят контрольной группы после лечения были выделены патогенные (Escherichia coli, Staphylococcus aureus, Enterococcus faecalis) и условно-патогенные микроорганизмы (Citrobacter diversus, Enterococcus faecium); в опытной группе - только условно-патогенные (Enterococcus faecium).

Сочетанное выпаивание настойки прополиса с антибиотиком по разработанной схеме увеличило содержание гемоглобина в крови цыплят опытной группы на 22,7 г/л, что свидетельствовало о насыщении крови кислородом и способствовало восстановлению и нормализации физиологических процессов после проведенного лечения. Это подтверждается и повышением содержания общего белка, глобулинов и БАСК в опытной группе на 7,3; 8,4 г/л и 36,9\% соответственно по сравнению с контролем. Продолжительность болезни цыплят контрольной группы составила 5 дней, опытной - 3 дня. Сохранность в опытной группе превышала контроль на $2 \%$,

\begin{tabular}{|c|c|c|}
\hline \multirow[t]{2}{*}{ Показатель } & \multicolumn{2}{|c|}{ Групnа } \\
\hline & Контрольная & Опытная \\
\hline \multicolumn{3}{|c|}{ Микробная обсемененность воздуха в залах после лечения, КОЕ/м³: } \\
\hline общее микробное число & 570,1 & $431,8^{* *}$ \\
\hline бактерии группы кишечной палочки & 646,2 & $54,3^{*}$ \\
\hline стафилококки & 485,0 & $315,1^{*}$ \\
\hline энтерококки & 19,0 & $6,1 *$ \\
\hline микроскопические грибы & 17,1 & $3,3 * *$ \\
\hline \multicolumn{3}{|c|}{ Содержание в крови бройлеров после лечения: } \\
\hline эритроциты, $10^{12 / л}$ & 2,8 & 2,9 \\
\hline гемоглобин, г/л & 92,9 & $115,6^{*}$ \\
\hline общий белок, г/л & 27,3 & $34,6 *$ \\
\hline альбумин, г/л & 14,6 & 13,6 \\
\hline глобулины, г/л & 12,7 & $21,7^{* *}$ \\
\hline БАСК, \% & 57,3 & 94,2 \\
\hline \multicolumn{3}{|l|}{ Экономические показатели: } \\
\hline сохранность, \% & 97,2 & 98,8 \\
\hline живая масса цыпленка после лечения, г & 626,9 & $738,6^{* *}$ \\
\hline среднесуточный прирост за период опыта, г & 29,5 & 39,9 \\
\hline ущерб от падежа птицы, руб. & 3269,1 & 1430,9 \\
\hline ущерб от снижения продуктивности птицы, руб. & 8164,8 & 4742,4 \\
\hline фактический ущерб от заболевания, руб. & 11433,9 & 6173,4 \\
\hline предотвращенный экономический ущерб, руб. & 4517,0 & 12626,8 \\
\hline экономический эффект от ветеринарных мероприятий, руб. & 1857,3 & 9286,7 \\
\hline эффективность ветеринарных мероприятий на рубль затрат, & , руб. 0,69 & 2,78 \\
\hline
\end{tabular}

живая масса и ее среднесуточный прирост - на 112 и 10,4 г соответственно. За период наблюдения отмечали увеличение потребления корма цыплятами опытной группы по сравнению с контролем на 4 г/гол./сут., что свидетельствовало о восстановлении аппетита и выздоровлении птицы, а снижение затрат корма на 1 кг прироста на 0,94 кг свидетельствовало об улучшении его усвоения.

При применении новой схемы лечения ущерб от падежа птицы снизился на 1838,08 руб., ущерб от снижения продуктивности - на 3422,4 руб., фактический ущерб на 5260,48 руб. Экономический эффект от ветеринарных мероприятий увеличился на 7429,4 руб., экономическая эффективность ветеринарных мероприятий на 1 руб. затрат - на 2,09 руб.

Заключение. Использование настойки прополиса в инкубаторе по разработанной схеме снижает микробный фон в период инкубации, не оказывает отрицательного действия на эмбрионы, повышает выводимость яиц на 4,8\%, вывод цыплят - на 4,2\%, санирует дыхательные пути птиц и способствует профилактике респираторных инфекций. Выпаивание и аэрозольная обработка настойкой прополиса по предлагаемым схемам с целью профилактики и лечения ассоциативных бактериальных респираторных инфекций цыплят-бройлеров снижает количество патогенных и условнопатогенных микроорганизмов в дыхательных путях птицы и в воздухе помещений, восстанавливает физиологические процессы, активизирует естественную резистентность и обмен веществ, снижает негативное влияние антибиотиков на организм птиц и ускоряет сроки их выздоровления при лечении, позволяет получать безопасную продукцию птицеводства 
без применения антибиотиков при профилактике, повышает продуктивность и экономические показатели при производстве мяса бройлеров.

Разработки подтверждены двумя патентами РФ: № 2709138 и № 2677985.

\section{Литература}

1. Новикова О.Б. Микрофлора, выделяемая в птицехозяйствах различного технологического направления и контроль бактериальных болезней птиц / О.Б. Новикова, М.А. Павлова // Вопросы нормативно-правового регулирования В ветеринарии. - 2018. - №3. - С. 34-36.

2. Красиков А.П. Мониторинг эпизоотической обстановки по инфекционным болезням птиц в ЗападноСибирском регионе и Алтайском крае / Красиков А.П., Рудаков Н.В., Крыцын В.Г. [и др.] // Роль ветеринарного образования в подготовке специалистов агропромышленного комплекса: Сб. науч. тр. - Омск: ИВМ ОмГАУ, 2003. - С. 163-171.

3. Калинин А.Н. Причины, способствующие возникновению заболеваний респираторного тракта у птиц / А.Н. Калинин, Т.Н. Рождественская, Е.В. Кононенко // Современные научные разработки и передовые технологии для промышленного птицеводства:
Мат. Юбил. конф. «25 лет НПП «АВИВАК». - СПб., 2015. - С. 14-18.

4. Лыско С.Б. Схемы профилактики и лечения респираторного и ассоциативного микоплазмоза птиц: дис. ... канд. вет. наук. - Омск, 2005. - 130 с.

5. Красиков А.П. Профилактика и лечение птиц при респираторном ассоциированном с эшерихиозом микоплазмозе / А.П. Красиков, И.Г. Трофимов, С.Б. Лыско, О.А. Сунцова, Н.Ф. Хатько // Ветеринарный врач. - 2013. - № 3. C. 40-43.

6. Лыско С.Б. Резистентность к энрофлоксацину и возможность ее преодоления / С.Б. Лыско, Л.М. Кашковская, М.И. Сафронова // Птицеводство. 2016. - №10. - С. 37-40

7. Анганова Е.В. Проблема антибиотикорезистентности возбудителей инфекционных болезней животных и птиц / Е.В. Анганова, А.М. Аблов, А.С. Батомункуев, А.А. Плиска // Вестник АПК Ставрополья. - 2017. - №2. - С. 55-58.

8. Панин А.Н. Проблема резистентности к антибиотикам возбудителей болезней, общих для человека и животных / А.Н. Панин, А.А. Комаров, А.В. Куликовский, А.А. Макаров //Ветеринария, зоотехния и биотехнология. - 2017. - № 5. - С. 18-24.

9. Ljubojevic D. Resistance to tetracycline in Escherichia coli isolates from poultry meat: epidemiology, policy and perspective / D. Ljubojevic, M. Pelic, N. Puvaca, D. Milanov // World's Poult. Sci. J. - 2017. - V. 73, No 2. - P. 409-417.

10. Технология инкубации яиц сельскохозяйственной птицы: метод. рекомендации / В.И. Фисинин [и др.]. Сергиев Посад: ВНИТИП, 2016. - 95 с.

11. Антонова Б.И. Лабораторные исследования в ветеринарии. Бактериальные инфекции: справочник / Б.И. Антонова, В.В. Борисова, П.М. Волкова [и др.]; под ред. Б.И. Антонова. М.: Агропромиздат, 1986. -352 с.

12. Госманов Р.Г. Практикум по ветеринарной микробиологии и иммунологии : уч. пособие / Р.Г. Госманов, Н.М. Колычев, А.А. Барсков. -Омск: Издательский дом «Лео», 2008. - 312 с.

13. Бессарабов Б.Ф. Лабораторная диагностика клинического и иммунобиологического статуса у сельскохозяйственной птицы / Б.Ф. Бессарабов, С.А. Алексеева, Л.В. Клетикова. - М.: Колос, 2008. - 152 с.

14. Лакин Г.Ф. Биометрия. - М.: Высшая школа, 1973. - 343 с.

Для контакта с авторами: Лыско Светлана Борисовна Задорожная Марина Валерьевна Тел.: +7 (3812) 937-272, 937-147 E-mail: vet@sibniip.ru

\title{
Application of Bee Glue Tincture for the Therapy and Prevention of Bacterial Respiratory Diseases in Broilers
}

\author{
Lysko S.B., Zadorozhnaya M.V.
}

\section{Omsk Agrarian Scientific Center}

Summary: Antibiotics are still most popular drugs for the therapy and prevention of respiratory diseases in poultry; however, the developing resistibility of the pathogens decreases their efficiency. The study presented was aimed at the development of therapeutically and economically effective protocols for the therapy and prevention of associated bacterial respiratory diseases in broilers using bee glue tincture (BCT) as a natural alternative to antibiotics. The trials were performed on incubating eggs and broilers of Ross-308 cross. The patented protocols developed for the treatment of eggs, chicks, and air with BGT were found to decrease contamination by pathogenic and opportunistic species of eggshell surface, respiratory tract of the chicks, the air of incubators and poultry houses; to increase hatchability of eggs and hatch of chicks by 4.8 and $4.2 \%$, respectively, in compare to formalin-treated control; to normalize physiological processes, activate natural resistibility and metabolism in chicks (as revealed by morphological and biochemical blood indices); to fasten the recovery of ill broilers; to allow biosafe broiler production without the preventive application of antibiotics; to improve productive performance and economic efficiency of broiler production.

Key words: respiratory diseases, bee glue tincture, broiler chicks, prophylaxis, therapy, incubator, bacterial 